DOI: https://doi.org/10.18371/fp.4(44).2021.243033

УДК 338.43

\title{
СТРАТЕГІЯ РОЗВИТКУ АГРАРНОЇ СФЕРИ ЕКОНОМІКИ У РЕГІОНАХ ПРИЧОРНОМОРСЬКОГО ЕКОНОМІЧНОГО РАЙОНУ УКРАЇНИ
}

\author{
БОРОВІК Любов Володимирівна \\ д.е.н., дочент, \\ професор кафедри економіки, підприємництва та економічної безпеки \\ Херсонський національний технічний університет \\ ORCID ID: http://orcid.org/0000-0001-7200-0497
}

\begin{abstract}
Анноватція. $B$ статті досліджено вплив чинників на економічний та інвестиційний розвиток сільського господарства Півдня України. Визначено основні стримуючі та стимулюючі чинники розвитку інновачійних прочесів в аграрних підприємствах. Встановлено, щуо інновачійна діяльність у сільському господарстві потребує збільшення державного фінансування товаровиробників та наукових установ.
\end{abstract}

Ключові слова: стратегія, інновачія, інвестииіï, регіональна економіка.

Постановка проблеми. Сільське господарство регіонів Причорноморського економічного району України $\epsilon$ однісю 3 провідних галузей, ефективність функціонування якої залежить від стану зрошувальних систем, функціонування переробних підприємств, наявність ринкової інфраструктури, обсягів залучення інвестицій, інноваційного потенціалу, якості підготовки спеціалістів, здатних забезпечити виконання інноваційно-інвестиційних програм. Маючи значні ресурси орної землі та водні запаси, найбільші в країні зрошувані масиви, мережу сільськогосподарських університетів та нау-
Аннотация. $B$ cmaтье исследовано влияние факторов на экономическое и инвестиционное развитие сельского хозяйства Юга Украины. Определены основные сдерживающие и стимулирующие факторы развития инновачионных прочессов в аграрных предприятиях. Установлено, что инноваџионная деятельность в сельском хозяйстве нуждается в увеличении государственного финансирования товаропроизводителей и научных учреждений.

Ключевые слова: стратегия, инновация, инвестиции, региональная экономика.

ково-дослідних установ, аграрна сфера району $є$ технологічно відсталою і не задовольняє потреби населення в повному обсязі продуктами харчування. Тільки глибокі економічні реформи та перехід на інноваційно-інвестиційну модель розвитку сільського господарства може вивести галузь 3 кризи, створити привабливі умови для залучення додаткових інвестицій.

Аналіз останніх досліджень і публікацій. Проблемам розвитку економіки аграрної сфери присвячені наукові праці І.П. Гайдуцького, Б.В. Губського, Б.М. Даніленка, М.В. Зубця, В.П. Ситника, Н.С. Танклевської та 
багатьох інших вчених-економістів. Але незважаючи на достатньо високий рівень вивчення цієї проблеми, процеси децентралізації державного управління та зростаюча роль регіонів у вирішенні власних економічних та фінансових питань потребують більш глибоких досліджень в аграрній галузі окремих економічних районів країни.

Метою статті є дослідження розвитку аграрної сфери економіки у регіонах Причорноморського економічного району України.

Виклад основного матеріалу дослідження. Активізація процесів регіоналізації для України є надзвичайно актуальною проблемою. Тому сучасна регіональна політика спрямована на прискорення соціально-економічного розвитку шляхом більш повного та ефективного залучення ресурсного потенціалу регіонів, використання переваг територіального поділу та кооперації виробничих потужностей різних секторів економіки 3 урахуванням місцевих особливостей господарювання. Маючи значні відмінності у своєму економічно-соціальному розвитку, кліматичних, грунтових, екологічних та інших характеристиках, кожен з регіонів України потребує індивідуального підходу 3 питань дослідження їх інвестиційної привабливості, конкурентоспроможності, управління інвестиційними ресурсами, доцільності інвестиційних вкладень в те чи інше виробництво сільськогосподарської продукції і сировини для переробних підприємств. Разом з тим, враховуючи однакові умови розвитку регіонів у межах окремих економічних районів України, доцільно досліджувати перспективи їх комплексного розвитку з метою поглиблення кооперації, покращення рівня інвестиційної привабливості, підвищення конкурентоспроможності сільського господарства. Що стосується Причорноморського економічного району до якого входять АР Крим, Миколаївський, Одеський та Херсонський регіони, то вони мають надзвичайно великі перспективи аграрного сектору економіки та переробної промисловості. Цьому сприяють:

a) наявність високопродуктивних земель сільськогосподарського призначення;

б) розвиненість переробної і транспортної інфраструктур;

в) наявність понад 90\% зрошуваних земель які є в Україні;

г) перспективи проведення капітальних робіт в зоні Каховської, Інгулецької, Каменської та інших зрошувальних систем;

д) прямий вихід до портів Чорного і Азовського морів, що забезпечує високі експортні можливості регіонів.

Велике значення для залучення інвестицій у сільськогосподарське виробництво має рівень впровадження інноваційних технологій, який активно впливає на поліпшення продукції, зниження іiі собівартості та підвищення конкурентоспроможності аграрних підприємств. Будівництво та функціонування комплексів для довгострокового зберігання овочів, фруктів і ягід дозволить товаровиробникам значно збільшити їх обсяг виробництва шляхом розширення посівних площ та переробки. Вже сьогодні УкраїноШведське підприємство «Чумак», що на Херсонщині, є лідером з виробництва і реалізації огірків у Європі.

3 метою посилення активності інвестування сільського господарства регіонів Причорноморського економічного району, необхідно: 
- відновити обсяги зрошувальної мережі до рівня 1996 року;

- покращити умови розвитку підприємства у сільській місцевості;

- стимулювати експорт овочів, плодів та ягід 3 метою завоювання ринків збуту в країнах ближнього і дальнього зарубіжжя;

- вжити заходів до спрощення режиму зовнішньоекономічної діяльності сільськогосподарських підприємств та інтегрованих аграрно-переробних об'єднань;

- здійснити наукові дослідження у сфері сучасного управління інвестиціями на рівні підприємства, регіону, міжрегіональних об'єднань, та ін.

Здійснюючи структурні перетворення у аграрній галузі, необхідно максимально використовувати можливості для створення міжрайонних та міжрегіональних аграрно-промислових об'єднань 3 повним циклом виробництва продуктів харчування. Такий підхід до економічного розвитку регіонів позитивно вплине на обсяги і якість виробництва аграрної продукції, сприятиме підвищенню рівня інвестиційної привабливості сільського господарства.

Аграрно-промислова інтеграція - це одна 3 форм інтенсифікації розвитку агропромислового комплексу, покращення його інвестиційної привабливості, поглиблення виробничих зв'язків та економіко-фінансових відносин між окремими учасниками об'єднання. Як економічна категорія, вона відображає систему економічних інтересів, що проявляються через відносини трудових колективів, аграрно-промислових формувань 3 державою, не інтегрованими підприємствами, населенням, а також в межах самого формування. При цьому, інтереси держави, насам- перед, визначаються забезпеченням сільськогосподарськими продуктами харчування населення, послабленням соціальної напруги, отриманням податків, участю інтегрованих формувань в регіональних, міжрегіональних та національних інноваційно-інвестиційних програмах соціальноекономічного розвитку. Тому держава, як одна із заінтересованих сторін в активізації інтеграційних процесів, повинна надавати інтегрованим об’єднанням пільги та вигідні замовлення, які гарантують їх економічний розвиток [1]. До того ж держава, як суспільно-політична організація, може укладати довгострокові угоди 3 інтегрованими структурами про взаємні зобов'язання: сплату податків та інших платежів інтегрованими суб'єктами господарювання 3 однієї сторони, та виконання фіскальних i інших 3обов'язань - 3 іншої.

Враховуючи напрями розвитку аграрної сфери економіки у регіонах Причорноморського економічного району, традиції господарювання на землі, розвиненість переробної галузі, високу активність фермерських та особистих селянських господарств, а також беручи до уваги світовий досвід, пропонуємо створення на півдні України аграрно-переробно-збутових кластерів. Саме регіональні кластери будуються 3 врахуванням місцевих чинників впливу на розвиток економіки та утворюються 3 ініціативи регіональних суб'єктів господарювання [2]. C.I. Соколенко, як один 3 ініціаторів запровадження в Україні мережевих структур, кластером вважає географічну концентрацію взаємопов'язаних підприємств та постачальників послуг типових для певного регіону [3]. Співпрацюючи у рамках кластеру, учасни- 
ки об'єднання оптимізують процеси взаєморозрахунків, авансування, товарного кредитування, спільного використання деяких основних засобів; при цьому, ефективно використовуючи спільну інфраструктуру та вирішуючи соціальні проблеми. 3 метою вирішення проблем неплатежів для взаєморозрахунків у таких об'єднаннях можливо застосувати вексельну форму розрахунків, що зменшить фінансову залежність учасників кластерних угрупувань від кредитних установ та сприятиме фінансовому оздоровленню підприємств. Розвиток спеціалізації та кооперації у кластерному утворенні може забезпечити високий рівень крупно-товарного виробництва з залученням у виробничий процес великих i малих сільгосппідприємства, фермерських і особистих селянських господарств, що стимулюватиме розвиток інвестиційних процесів у сільському господарстві. Державні та регіональні органи влади повинні бути зацікавленні у прискоренні інтеграційних процесів, так як економічні процеси ставатимуть більш керованими, інвестиційні ресурси концентруватимуться на пріоритетних напрямах, а їх використання буде більш ефективним. Враховуючи досвід впливу іноземних держав на розвиток сільського господарства у своїх країнах, високий рівень корумпованості в Україні, недосконалість процесів реформування АПК, а також те, що держава $є$ активним суб'єктом земельних відносин регулює ринок землі та здійснює заходи по збереженню іiі родючості, є власником зрошувальної мережі та водних ресурсів, вона повинна мати представництво у кластерних об'єднаннях на півдні країни. Являючись найбільшим інвестором аграрної галузі, дер- жава повинна здійснювати контроль за ефективністю використання інвестованих у виробництво коштів та своєчасність їх повернення у відповідність до чинного законодавства. Тільки держава може активно впливати на розвиток спеціалізації у господарствах, створюючи тим самим передумову побудови кластерів зернокруп'яного, м'ясо-молочного, плодоовочевого та інших спрямувань. Не втручаючись у господарську діяльність, а застосовуючи систему засобів, важелів, методів і стимулів, держава повинна створювати сприятливе середовище для розвитку кластеризації, спрямовуючи діяльність у русло, в якому б поєднувалися інтереси держави, регіону, учасників об'єднань та суспільство. Особливу увагу державі потрібно приділяти поглибленню співпраці між особистими селянськими господарствами та кластерами. Для цього, необхідно активізувати роботу районних дорадчих служб у напрямі консультативного обслуговування селян 3 питань ефективного використання ресурсного потенціалу, прогресивних технологій на відносно невеликих земельних ділянках та створення виробничо-збутових кооперативів на селі. Підтримуючи розвиток особистих селянських господарств та відстоюючи їх інтереси у кластерах, держава стимулюватиме розвиток всього аграрно-промислового комплексу.

Надзвичайно великого значення в економічному розвитку регіонів та їх інвестиційній привабливості повинен відігравати лізинг, який є одним 3 основних засобів оновлення технічної i технологічної бази аграрних та промислових підприємств у більшості країн світу. Так, лізингове інвестування у загальному державному обсязі інвес- 
тицій в таких країнах як Румунія, Чехія, Угорщина, Польща становить відповідно $30,8 \%, 20,3 \%, 20,1 \%, 9,1 \%$. Що стосується України, то цей вид економічної діяльності тільки починає розвиватися [4]. За даними Всеукраїнської асоціації «Укрлізинг», щорічно лізингові операції здійснюються на суму від 2,0 до 2,5 млрд. грн. Їх частка у валових інвестиціях не перевищує $4,0 \%$, що вказує на низький рівень розвитку ринку лізингових послуг в Україні. На сьогоднішній день НАК «Украгролізинг» $є$ найбільшою лізинговою компанією, яка відіграє головну роль у технічному забезпеченні аграрних підприємств. Разом 3 цим, не маючи достатніх коштів, ця компанія щорічно здійснює фінансові послуги на суму до 5 млн. грн. у розрахунку на кожен регіон України. Оскільки 100\% акцій компанії $є$ власністю держави, незадовільний іiі фінансовий стан гальмує розвиток фінансового лізингу у аграрно-промисловому комплексі. Також негативно впливають на розвиток лізингу існуючий недосконалий фінансово - кредитний механізм, громіздкість здійснення лізингових операцій, низька купівельна спроможність аграрних і фермерських підприємств, небажання комерційних i державних банків кредитувати особисті селянські господарства.

Спираючись на результати досліджень, можна з впевненістю констатувати, що створити повноцінний, конкурентоспроможний ринок лізингових послуг в АПК та подолати кризу у сільському господарстві можливо лише за умови прийняття державної Програми переходу сільського господарства на інноваційну модель розвитку, відновлення вітчизняного машинобудування, створення сприятливих умов для плідної співпраці з іноземними інвесторами в аграрній сфері економіки, підготовки сучасних спеціалістів для села на оновленій матеріально-технічній базі реформованих аграрних університетів.

До основних чинників, що стримують розвиток інноваційних процесів в аграрних підприємствах слід віднести:

- слабку фінансову та матеріальнотехнічну базу суб'єктів виробництва;

- відсутність розвинутого ринку інноваційних технологій в АПК;

- недостатне фінансування наукових установ $з$ боку держави;

- високі ризики реалізації масштабних наукових досліджень;

- відсутність механізму конкурсного відбору наукових розробок на рівні інноваційних проектів, що впроваджується у аграрне виробництво, та ін.

3 боку держави важливим важелем впливу на пожвавлення інноваційної діяльності у галузі могло б бути: фінансування розробок новітніх технологій; пряме фінансування регіональних інноваційних проектів на початкових етапах їх розробок; надання відповідних пільг підприємствам, які займаються впровадженням інноваційних проектів. Однією 3 головних складових стратегічного напряму інноваційного розвитку сільського господарства повинно бути докорінне реформування вищих навчальних закладів та науково-дослідних інституцій 3 метою максимального їх зближення 3 аграрним виробництвом. Тому у сфері науки та вищої освіти головним має бути: значне підвищення якості освіти; створення належних умов для ведення наукової діяльності; зміцнення зв'язків між науковими установами та вищими навчальними закладами 3 метою поліпшення про- 
фесійної підготовки кадрів для села та підвищення рівня науководослідницької діяльності; більш активне залучення науковців до розробки та впровадження у виробництво інноваційно-інвестиційних програм. Створення на базі університетів та науково-дослідницьких інститутів технологічних парків та бізнес-інкубаторів забезпечить технологічний трансфер, активізація комерціалізацію наукових розробок, скоротить терміни між розробкою інноваційних технологій та отримання інноваційного продукту, дозволить здійснювати професійну підготовку студенів на рівні Європейських стандартів. Вже сьогодні, на базі існуючих регіональних навчальних закладів та наукових установ, необхідно більш активно створювати міжрегіональні науково-навчальні інноваційні центри, які могли б готувати кадри для села, що здатні очолити виробничі підрозділи з відновлення зрошувальних систем, впровадження інноваційних технологій в аграрній галузі, забезпечуючи тим самим економічний i соціальний розвиток Причорноморського економічного району. Такий підхід до розвитку науково-навчальної бази на півдні України значно підвищить рівень конкурентоспроможності регіонів, сприятиме додатковому притоку інвестицій як у виробничу сферу так і соціальну, закріпленню трудових ресурсів у сільській місцевості. Створення міжрегіональної інформаційної мережі забезпечення безперебійності інвестиційного процесу дасть можливість інвесторам своєчасного і швидко знайомитися 3 інформацією про можливість і умови вкладення коштів у тому чи іншому регіоні району, сприятиме створенню міжрегіональних науково-виробничих кластерів та поглиб- ленню міжрегіональної інтеграції у Причорноморському економічному районі як важливому чиннику підвищення рівня продовольчої безпеки країни.

\section{Висновки.}

1. Регіони Причорноморського економічного району, плануючи свою економічну, фінансову й соціальну політики розвитку сільських територій, повинні враховувати власний досвід господарювання на землі, досвід інших регіонів України та здобутки зарубіжних країн. Стратегічний розвиток сільського господарства повинен базуватися на формуванні ринкового середовища, сприятливого інвестиційного клімату, активізації процесів кооперації та інтеграції в агропромисловому комплексі.

2. Враховуючи напрями розвитку аграрної сфери економіки у регіонах Причорноморського економічного району, високу активність сільськогосподарських підприємств, фермерських та особистих селянських господарств, а також розвиненість переробної галузі й логістики доцільно створювати аграрно-переробно-збутові кластери, як одну 3 форм інтегрованих об'єднань суб'єктів господарської діяльності.

3. Основою розвитку аграрного сектору економіки має бути високий рівень інноваційного потенціалу. Підготовка наукових кадрів, створення Банку інноваційних розробок та координаційних центрів у регіонах, які б об’єднували зусилля науковців і виробників сприяло б прискоренню переходу на інноваційно-інвестиційну модель розвитку сільського господарства. Впровадження сучасних технологій та розвиток ринку лізингових послуг позитивно б вплинуло на здешев- 
лення виробленої продукції та підви- Причорноморського економічного ращення конкурентоспроможності агра- йону. рного сектору економіки регіонів

\section{Список використаної літератури}

1. Нестерчук Ю.О. Участь держави у розвитку інтеграційних процесів в АПК. Вісник ХНТУ СГ, 2007. Вип. 56. С. 205-210.

2. Танклевська Н.С., Боровік Л.В. Концептуальні засади удосконалення інвестиційної політики розвитку сільського господарства. Науковий вісник Ужсгородського національного університету. Серія Міжнародні економічні відносини та світове господарство, 2019. Вип.26. Ч.1. С. 24-28.

3. Петіна Л.В. Шляхи удосконалення внутрішньогосподарської звітності та перманентної інвентаризації в прийнятті управлінських рішень на підприємствах АПК. Бізнес - навігатор, 2009. № 2 (17). С. 147 - 151.

4. Шандова Н. В. Джерела підвищення продуктивності праці. Проблеми системного підходу в економіці, 2019. Випуск 2(70). С.32-37.

5. Тарасюк А.В. Особливості управління маркетинговою діяльністю аграрного підприємства України. Агросвіт, 2019. №17. С. 70 - 78.

6. Танклевська Н.С., Боровік Л.В. Вплив інвестиційної політики на формування економічного інвестиційного потенціалу сільського господарства. Науковий економічний журнал «Інтелект XXI», 2019. №3. С. 121-125.

7. Петренко В.С., Карнаушенко А.С. Фактори підприємницького зовнішньоекономічного ризику в умовах глобалізації. Інтелект XXI, 2018. №1. С. 24-28.

8. Trusova, N.V. et al. Investment Attractiveness of the Economy of the World Countries in the Polystructural Space of Foreign Direct Investments. Journal of Advanced Research in Law and Economics, 2020. Volume XI, Spring, 2(48): 645 660. DOI: 10.14505/jarle.v11.2(48).35. Available from: http://journals.aserspublishing.eu/jarle/index.

9. Олійник Н. М., Соловйова Н.І., Макаренко С.М. Методологічна коректність оцінювання параметрів соціально - економічного розвитку регіонів. Актуальні проблеми економіки, 2016. №11 (185). С. 268 - 277.

10. Карлюка Д.О., Мєшкова-Кравченко Н.В., Бурик Ю.І. Визначення шляхів підвищення ефективності функціонування птахівничих підприємств за допомогою технології «Data Mining». Вісник Хмельницького національного університету: Економічні науки, 2016. №3. Т. 1 (236). С. 22 - 27.

11. Латкіна С.А., Мєшкова-Кравченко Н.В. Підприємницькі ризики в інноваційній діяльності підприємства. Науково - виробничий журнал «Бізнес - навігатор», 2018. № 32 (46). C. 26 - 29. 